\title{
NOISE ASSESMENT AND MITIGATION SCHEMES FOR ESTONIAN AIRPORTS
}

\author{
Signe Vanker ${ }^{1}$, Mart Enneveer ${ }^{2}$, Imre Rammul ${ }^{3}$ \\ ${ }^{1,2}$ Estonian Aviation Academy, Tartu, ${ }^{3}$ Estonian Air Navigation Services, Tallinn, Estonia

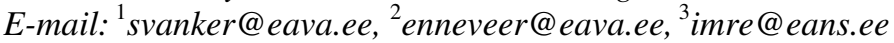

Received 6 February 2009, accepted 4 March 2009
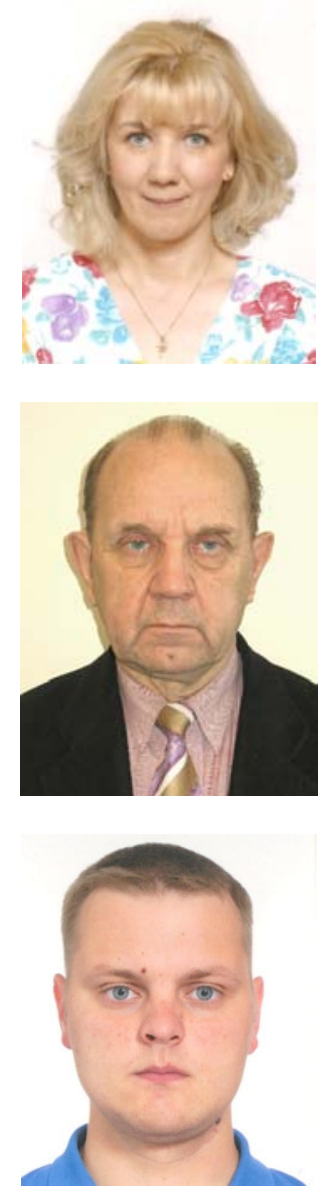

Signe VANKER, Phd

Date and place of birth: 1966, Tartu, Estonia.

Education: 1989-Estonian Agricultural Academy (cum laude), 2006-master's degree in school management, University of Tartu. Affiliations and functions: Since 2008-head of Studies Department of Estonian Aviation Academy, since 2007-Ph D student at Tallinn University (Ecology).

Research interests: aviation and environmental protection.

Publications: five scientific papers.

\section{Mart ENNEVEER, Prof}

Date and place of birth: 1939, Tartu, Estonia. Education: 1963-Tartu State University 1974-Cand. of Sci. (Biology), Estonian Academy of Sciences.

Affiliations and functions: Since 2003-professor at Tartu Aviation College (since 2008 Estonian Aviation Academy); since 2000-chair of Aviation Company Management of Tartu Aviation College (since 2008 Estonian Aviation Academy); 1994-1999-Development Director of Tartu Aviation College.

Research interests: aviation and environmental protection.

Publications: two books and forty-one scientific paper.

\section{Imre RAMMUL}

Date and place of birth: 1984, Tartu, Estonia.

Education: 2008-Tartu Aviation College.

Affiliations and functions: Since 2008-aeronautical information management specialist, Estonian Air Navigation Services.

Research interests: aviation and environmental protection.

\begin{abstract}
In recent years, concern over airport noise and its impact on surrounding communities has been spurred by the continual growth in air traffic together with urban development in close proximity to many airports around the world. This paper aims at studying the cases of Tallinn Airport and Tartu Airport, both in Estonia, with a focus on evaluating the airport noise and its impact on the neighbouring residential districts. Tallinn Airport is located within the city limits (only 4 kilometres from the city centre), and therefore the inhabited areas are also exposed to aviation noise. The main water catchment area for the city - Lake Ülemiste - and the nearest residential district are situated about $0.5 \mathrm{~km}$ from the airport. In 2003 stationary noise monitoring equipment was installed at Tallinn Airport to measure the noise level caused by starting and landing aircraft so that the necessary measures and sanctions can be taken. At Tartu Airport, the noise was recurrently measured in 2008, by using a TES 1352A sound level meter. The
\end{abstract}


monitoring system at Tallinn Airport and the measurements at Tartu Airport enable operating noise and aircraft noise to be analyzed and predicted as a way to differentiate the landing fees for aircraft depending on noise and flight trajectory. According to the noise monitoring and measurements results, noise maps can be drawn.

Keywords: airport noise, airport environmental impact, noise measurements, noise monitoring, noise level, noisiest aircraft, noise maps, mitigation schemes

\section{Introduction}

Aviation is a critical component of the global economic infrastructure. If there is to be growth in aviation, however, the environmental impact of aviation must be mitigated (Clarke 2003) The operation of airports results in environmental impacts associated with high levels of noise and vibration (Mato et al. 1999) In recent years, concern about airport noise and its impact on surrounding communities has been spurred by the continual growth in air traffic together with urban development in close proximity to many airports around the world (Arafa et al. 2007)

Noise pollution is an often forgotten environmental problem that is steadily growing in developing countries (Barboza et al. 1995) Noise pollution has been recognized as a serious health hazard (Bies et al. 1996)

The World Health Organization (WHO) recommends a noise level of less than $35 \mathrm{~dB}$ (A) Leq. during the restorative process of sleep (Mufuruki 1997) It is also often asserted that noise reduces output and efficiency and affects morale. Long-term exposure to noise levels of about $90 \mathrm{~dB}$ (A) may lead to permanent hearing loss while prolonged exposure to sounds of 100 $\mathrm{dB}$ (A) may cause irreparable damage to the auditory organs. A noise level of about $120 \mathrm{~dB}$ (A) is considered painful and may cause instantaneous loss of hearing, while more than $140 \mathrm{~dB}(\mathrm{~A})$ may produce insanity.

\section{Overview of Tallinn and Tartu airports 2.1.Tallinn Airport}

Tallinn, the capital of Estonia, is located along the Baltic coast. There are five international airports in Estonia, but only Tallinn Airport has considerable passenger traffic. Tallinn Airport belongs to the category 4E (general), Cat I (navigation), and 7 (fire-rescue), and its runway is $3070 \mathrm{~m}$ long and $45 \mathrm{~m}$ wide. From the point of view of environment protection, the location of Tallinn Airport is not good because the airport is located very near to the city (only $4 \mathrm{~km}$ south-east of the Tallinn city centre). The main water resource for city needs - Lake Ülemiste - and the nearest residential district are situated about $0.5 \mathrm{~km}$ from Tallinn Airport. The closest coherent residential areas are situated in Mõigu, about $500 \mathrm{~m}$ south-west of the airport, and Sikupilli, about $1500 \mathrm{~m}$ north-west of it. The airport produces noise during both development and operational phases. Crucial issues involve the location of airport users and employees and the flight path and engine testing during operation of the airport. Although one of the districts of Tallinn is situated under the trajectory of aircraft taking off and landing, the inhabitants of Tallinn have very seldom lodged protests against the noise.

\subsection{Tartu Airport}

Tartu Airport has an important role in Estonian regional policy as an educational centre and gateway to Europe. Tartu Airport is also important in the regional development of the southern part of Estonia; there is a plan to begin regular flights to attract enterprises and tourists to southern Estonia. The length of the runway is $1,799 \mathrm{~m}$ and its width is $31 \mathrm{~m}$. The load capacity of the runway is 65 tonnes.

\section{The objectives of the study}

The objectives of this study were:

\subsection{Tallinn Airport}

- $\quad$ to measure the noise levels generated by aircraft at Tallinn Airport and it surroundings,

- to specify the noisiest types of airplanes at Tallinn Airport,

- to suggest measures for reducing noises or their impacts.

\subsection{Tartu Airport}

Research work was focused on the survey of aviation noise at Tartu Airport. There have been several complaints about the noise in the areas surrounding Tartu Airport. The main goal of this research was to find out whether the maximum noise level of flight operations exceeded the allowed levels or not.

\section{Noise measurements}

\subsection{Tallinn Airport}

In 2003 stationary noise monitoring equipment was installed at Tallinn Airport to measure the level of noise caused by starting and landing aircraft so that the necessary measures and sanctions can be taken.

At present Tallinn Airport has the following device for metering and modelling the noise level:

- two stationary noise level monitoring terminals,

- one mobile terminal,

- $\quad$ software to monitor flight-trajectories (company Topsonic),

- software for modelling the noise level (Danish method).

One stationary monitoring station is located on the grounds of the airport and surrounded by a fence. Data is transferred from the stationary noise monitoring terminals grounds of the airport to the central unit by cable.

One stationary monitoring station located outside the grounds of the airport. Data transferred from the 
stationary noise monitoring terminals outside the grounds of the airport to the central unit by using lines of Estonian Telecom.

One station is equipped with weather sensors to measure the wind speed, wind direction, temperature, and air pressure.

According to the noise monitoring and measurement results at Tallinn Airport, noise maps were prepared (Appendices).

\subsection{Tartu Airport}

Measurements took place on 7 April 2008 during training flights. The measurements were carried out at the end of the landing flights on the $26^{\text {th }}$ runway, by the NDB beacon, and in the living area situated at the end of the same runway. The measurement results were registered and the places of measurements were marked on a map. The measurement duration of the noise event was 1 minute on the average. The measurement device was held over the head of the measurer to achieve the most adequate results and also to achieve conditions that were similar to the conditions in an open area. The type of plane that performed the training flights was a "Piper Navajo PA-31-310". No regular commercial air traffic has been operated by Tartu Airport since 2001. The airport facilities have been used mainly as a training base for student pilots who are studying at the Estonian Aviation Academy. For training flights, training planes such as the "Cessna 172" and "PA-31-310" (Piper Navajo) are used. The noise generated by the doubleengine "Piper Navajo PA-31-310" is considerably higher than that made by the "Cessna 172". It was this higher noise level emanating from the "Piper Navajo PA-31310 " that provided the need for recurrent measurements of noise at Tartu Airport in 2008. The correction of the background noise was done according to formula 1 .

$$
L_{a t}=10 \times \log \left(10^{\frac{L}{10}}-10^{\frac{L_{b}}{10}}\right)
$$

where $\mathrm{L}_{\mathrm{at}}$ - corrected noise level, $\mathrm{dB} ; \mathrm{L}$ - summarized noise level, $\mathrm{dB} ; \mathrm{L}_{\mathrm{b}}$ - background level, $\mathrm{dB}$.

\section{Results and discussion 5.1. Tallinn Airport}

A peculiarity of air traffic distribution in Tallinn is that only about $18 \%$ of take-off and approaches take place above the city, west of the airport, and $82 \%$ above the not densely built-up land east of the airport (Tab 1).

The following table shows the runway use for overall traffic in 2008.

Table 1. Runway use for overall traffic in 2008

\begin{tabular}{|c|c|c|}
\hline Number of flights & \multicolumn{2}{|c|}{ RWY usage \% } \\
\hline \multirow{2}{*}{176,464} & RWY 08 & RWY 26 \\
\cline { 2 - 3 } & 17.87 & 82.13 \\
\hline
\end{tabular}

As the annual average traffic is relatively small in/from western directions, the area exposed to relevant noise input is smaller in the west than in the east. To maintain take-offs and landings from eastern directions as the preferred options is regarded as an appropriate mitigation measure concerning increasing air traffic. Already the current permits for airport operations state that at night only these flight directions are normally allowed. When the wind from the west is not too strong, landings from and departures in eastern directions are anyway more favourable.

The noisiest types of airplanes at Tallinn Airport are the "IL 62" and "AN 124" (Fig 1).

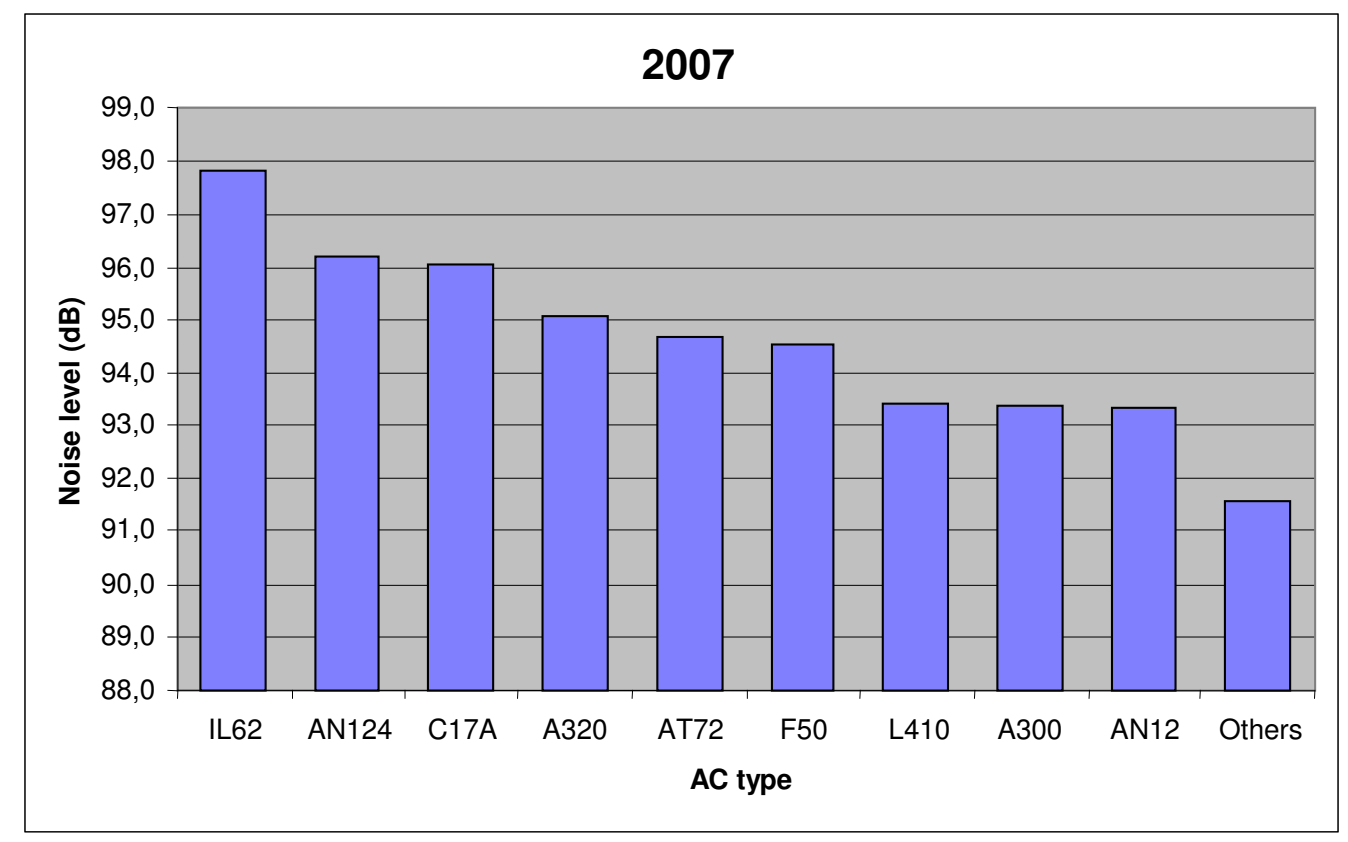

Fig 1. Airplanes emitting the highest noise level dB 


\subsection{Tartu Airport}

Table 2 presents the maximum values of each measurement of sound pressure in decibels on an Acorrected scale, and the average noise level during the measurement period. Maximum values are reached by processing the data obtained afterwards.

If taken as a premise that the levels given in table 2 are maximum aggregate noise levels, we can calculate the corrected noise levels by formula (1). The results of the calculation are given in table 3.

Table 2. Maximum values of sound pressure $\mathrm{L}_{\mathrm{pA} \text {,max }}$ and the average value of sound pressure during measurement period

\begin{tabular}{|c|c|c|c|}
\hline Location & Type of aircraft & $\begin{array}{c}\text { Maximum sound } \\
\text { pressure level } \\
\mathrm{L}_{\mathrm{pA} \text { max }}(\mathrm{dBA})\end{array}$ & $\begin{array}{c}\text { Average sound } \\
\text { pressure value } \\
\text { during } \\
\text { measurement } \\
\text { period (dBA) }\end{array}$ \\
\hline NDB (measurement 1) & Piper Navajo PA-31-310 & 83.2 & 63.3 \\
\hline NDB (measurement 2) & Piper Navajo PA-31-310 & 84.4 & 61.8 \\
\hline NDB (measurement 3) & Piper Navajo PA-31-310 & 88.6 & 64.7 \\
\hline Crossroad & Piper Navajo PA-31-310 & 79.9 & 59.0 \\
\hline Field next to residential area & Piper Navajo PA-31-310 & 89.4 & 63.1 \\
\hline Within residential area (meas. 1) & Piper Navajo PA-31-310 & 79.4 & 53.5 \\
\hline Within residential area (meas. 2) & Piper Navajo PA-31-310 & 78.5 & 54.7 \\
\hline
\end{tabular}

Table 3. Maximum corrected noise levels dBA

\begin{tabular}{|c|c|c|}
\hline Location & Type of aircraft & $\begin{array}{c}\text { Max corrected sound } \\
\text { pressure level } \text { Lat,max }_{\text {(dBA })}\end{array}$ \\
\hline NDB (measurement 1) & Piper Navajo PA-31-310 & 83.19 \\
\hline NDB (measurement 2) & Piper Navajo PA-31-310 & 84.39 \\
\hline NDB (measurement 3) & Piper Navajo PA-31-310 & 88.60 \\
\hline Within residential area (measurement 1) & Piper Navajo PA-31-310 & 79.40 \\
\hline Within residential area (measurement 2) & Piper Navajo PA-31-310 & 78.50 \\
\hline
\end{tabular}

\subsection{Mitigation schemes for Tallinn Airport}

Mitigation schemes for Tallinn Airport include the following noise abatement procedures (Aeronautical... 2008):

1. General provisions - noise abatement procedures are applicable below the altitude of 3000 FT MSL.

2. Preferential runways :

a) take-off: RWY 08; RWY 26;

b) landing: RWY 26; RWY 08.

3. Special procedures - IFR flights departing from RWY 26 shall adhere to procedure A defined in ICAO Doc 8168-OPS/611 volume 1, part 5:

a) take-off to $1500 \mathrm{FT}$ above aerodrome elevation:

- take-off power,

- take-off flap,

- climb at V2 +10 to $20 \mathrm{KT}$ (or as limited by body angle).

b) at $1500 \mathrm{FT}$ :

- reduce thrust to not less than climb power/thrust.

c) $1500 \mathrm{FT}$ to $3000 \mathrm{FT}$ :

- climb at $\mathrm{V} 2+10$ to $20 \mathrm{KT}$.

d) at $3000 \mathrm{FT}$ :

- accelerate smoothly to en-route climb speed with flap retraction on schedule.

4. Use of the runway at night: a) RWY26 is not used between 2000 and 0400 for departures of aircraft with MTOW exceeding 136 tonnes;

b) exceptions are subject to CAA permission and will be accepted for justified reasons only.

5. Training flights - no limitations.

6. Maintenance run-up - Maintenance run-ups of aircraft engines must be avoided between 2000 and 0400 and at any time on Sundays.

\subsection{Mitigation schemes for Tartu Airport}

As can be seen, the result obtained does not exceed the maximum daily critical level of sound pressure of $\mathrm{L}_{\mathrm{pA} \text {,max }}=90 \mathrm{dBA}$ in any of the locations measured. Yet, in two cases the sound pressure level was higher than the maximum noise level (which is $85 \mathrm{dBA}$ in the daytime) allowed for sound pressure caused by air traffic.

The residential area where measuring was carried out is also, in addition to being located beneath the air corridor, exposed to railway traffic and the noise arising from that.

When selling a plot of land, a real estate developer has the task of informing the client about the neighbouring infrastructure. It is up to the concrete client whether to move into the vicinity of an airport or not, as an airport cannot move anywhere else. 
In general it is forbidden to build new noise sensitive buildings in areas where the noise level exceeds the maximum critical level of sound pressure.

\section{Conclusions}

The purpose of noise monitoring is to inform the airport, airlines, local community and government about noise pollution. According to noise monitoring results and noise modelling, noise maps can be drawn. With the help of a noise monitoring system, it can be controlled that aircraft will proceed in its trajectory. It is important that the aircraft will not make louder noise than $85 \mathrm{dBA}$ at the measurement points. The noisiest airplanes at Tallinn Airport are the IL 62 and AN 124.

The results of the measurements made by the authors of this paper at Tartu Airport indicate that the maximum levels of noise allowed were not exceeded. But still, the noise exceeded the allowed air traffic noise level on two occasions. The biggest margin between the allowed level and the measurement result was 4.4 decibels. That is not very significant but actually still very disturbing for the residents living in an area affected by noise pollution.

It is evident that the reopening of regular flights will have an effect on the noise level in the vicinity of the airport. But since the planned number of flight operations per day does not show dramatical increase, all noise levels will remain within the norms in the future as well. The noise level also certainly depends on the type of aircraft selected for the given flight and on the amount noise emitted by those aircraft.

One has to take notice of the peculiarities of take-off and landing procedures as well. When the Tartu Airport runway is made longer, the take-off can be started from further away at the beginning of runway 08. This will enable the airplane to gain more altitude before flying over the inhabited area. Less noise will reach the ground from the greater altitude, and thus the noise level will be lower. And after the installation of the ILS, the approach procedures will be less dangerous and more accurate.

\section{References}

Aeronautical Information Publication (AIP)[online]. 2008. [cited 15 September 2008]. Available from Internet: <http://aip.eans.ee/>.

Arafa, M. H.; Osman, T. A.; Abdel-Latif, I. A. 2007. Noise assesment and mitigations schemes of Hurghada airport. Applied Acoustics. (68): 13731385 .

Barboza, M. J.; Carpenter, S. P.; Roche, L. E. 1995. Production of traffic noise: A screening technique. Journal of Air and Waste Management Assoceation, (45): 703-708.

Bies, D. A.; Hansen, C. H. 1996. Engineering noise control: Theory and practice, $2^{\text {nd }}$ ed. London.

Clarke, J.-P. 2003. The role of advanced air traffic management in reducing the impact of aircraft noise and enabling aviation growth. Journal of Air Transport Management, (9)): 161-165.

Mato, R. R. A. M.; Mufuruki, T. S. 1999. Noise pollution associated with the operation of the Dar es Salaam International Airport. Transportation Research. Part D, (4): 81-89.

Mufuruki, T. S. 1997. Evironmental impacts arising from the operation of Dar es Salaam International Airport. In Advanced Diploma Project. Dar es Salaam: Environmental Engineering Dept.

\section{GARSINIO UŽTERŠTUMO İERTINIMAS IR JO MAŽINIMO SCHEMOS ESTIJOS ORO UOSTUOSE}

\section{S. Vanker, M. Enneveer, I. Rammul}

S a n tra k a

Pastaraisiais metais nerimo faktorius, atsiradęs dèl triukšmo, sukeliamo oro uostuose ir jo poveikio aplinkiniams gyvenamiesiems rajonams, tapo rimtesnis, nes gausėja orlaivių, taip pat oro uostai įsikuria per arti gyvenamujų rajonų.

Šių tyrimų tikslas buvo nustatyti Talino ir Tartu oro uostų keliamo triukšmo lygi bei jo įtaką aplinkiniams gyvenamiesiems rajonams.

Tarptautinis Talino oro uotas yra įsikūręs miesto ribose (tik $4 \mathrm{~km}$ atstumu nuo miesto centro). Tai reiškia, kad nemažai gyventoju kenčia nuo orlaivių keliamo triukšmo. Pati artimiausia gyvenvietė yra nutolusi nuo oro uosto tik $0,5 \mathrm{~km}$ atstumu. Julemistès ežeras, kuris yra miesto geriamojo vandens šaltinis, taip pat yra oro uosto apylinkèse.

2003 m. Talino oro uoste buvo pastatyta triukšmo lygio matavimo įranga, kuri turèjo ne tik nustatyti kylančiu ir besileidžiančių orlaivių sukeliamo triukšmo lygị, bet ir numatyti būtinas priemones jam sumažinti bei taikyti sankcijas. 2008 m. Tartu oro uoste triukšmas matuotas kelis kartus naudojant triukšmo matuokli TES 1352A.

Ši triukšmo matavimo sistema leidžia pirmiausia išanalizuoti ir nustatyti orlaivių bei kitos ịrangos keliamo triukšmo lygi ir tuomet diferencijuoti rinkliavas už nusileidimą, kurios priklauso nuo sukeliamo triukšmo lygio ir skrydžio trajektorijos. Priklausomai nuo triukšmo kontrolès ir jos rezultatų, galima nupiešti triukšmo žemėlapius.

Reikšminiai žodžiai: oro uosto triukšmas, oro uosto aplinkos įtaka, triukšmo matavimas, triukšmo lygis, triukšmingiausi orlaiviai, triukšmo žemèlapiai, sumažinimo schemos. 


\section{Appendices}

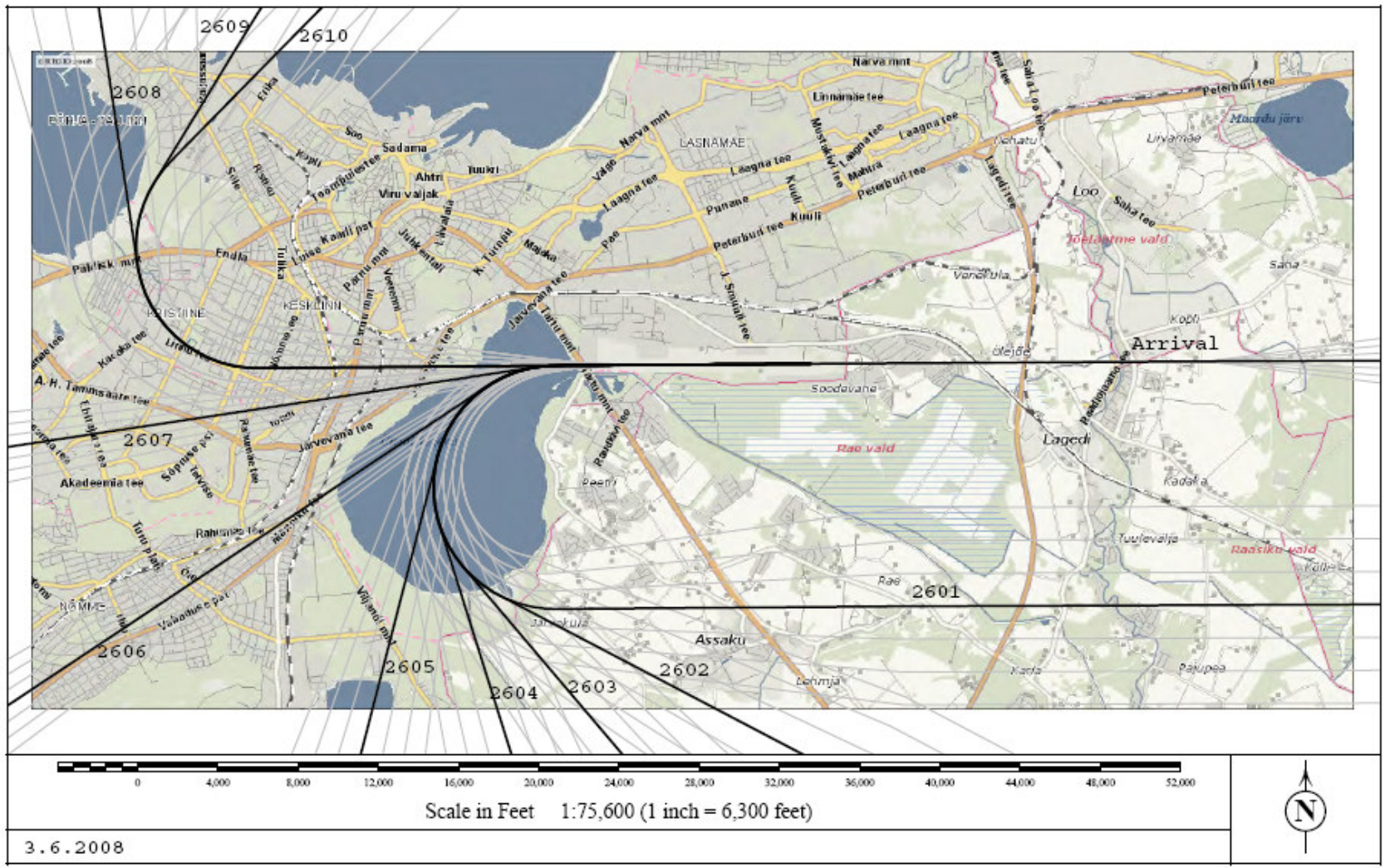

Fig 1. Tallinn Airport. Noise map according to Directive 2002/49/EC. Air corridors of runway 26

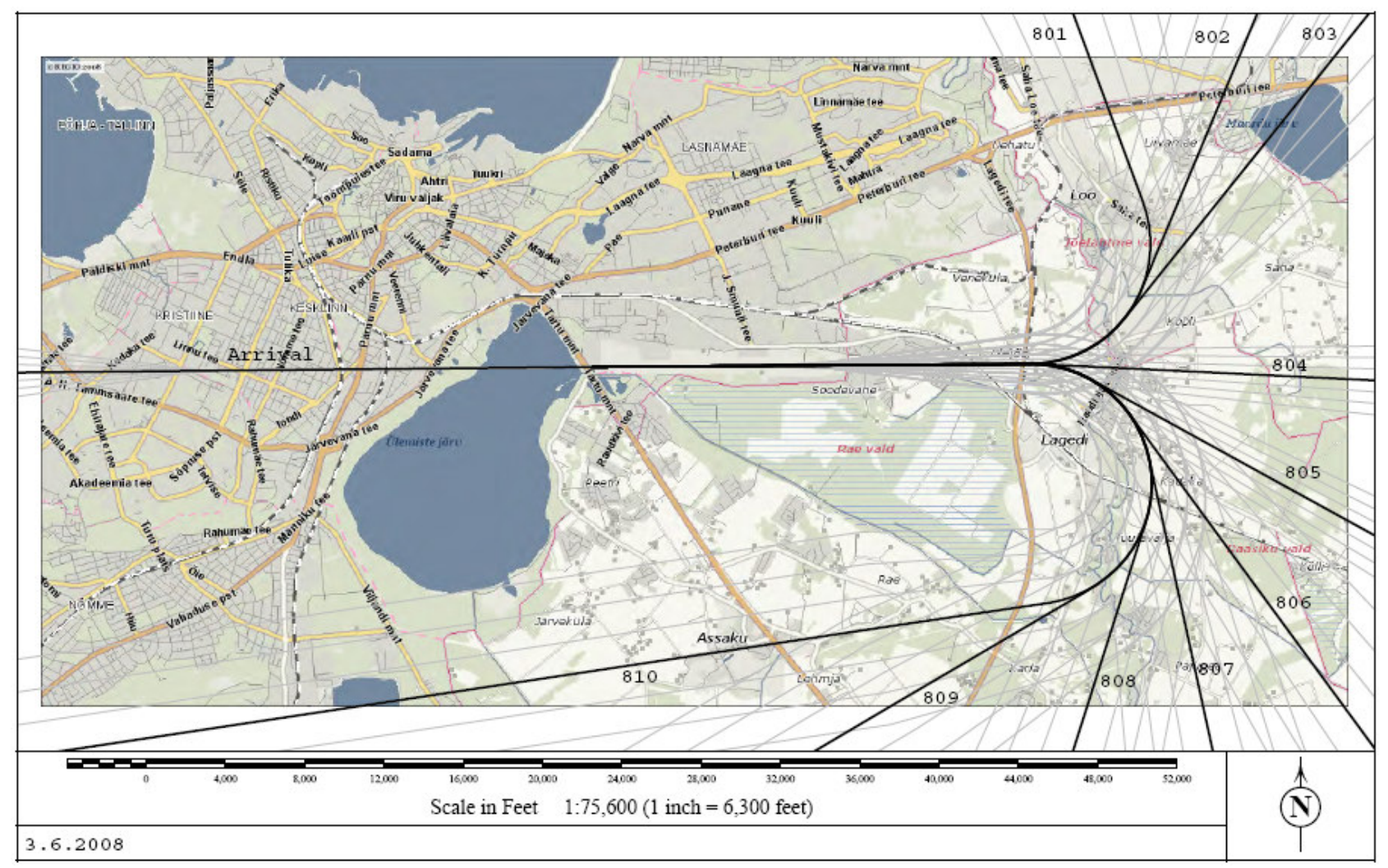

Fig 2. Tallinn Airport. Noise map according to Directive 2002/49/EC. Air corridors of runway 08 


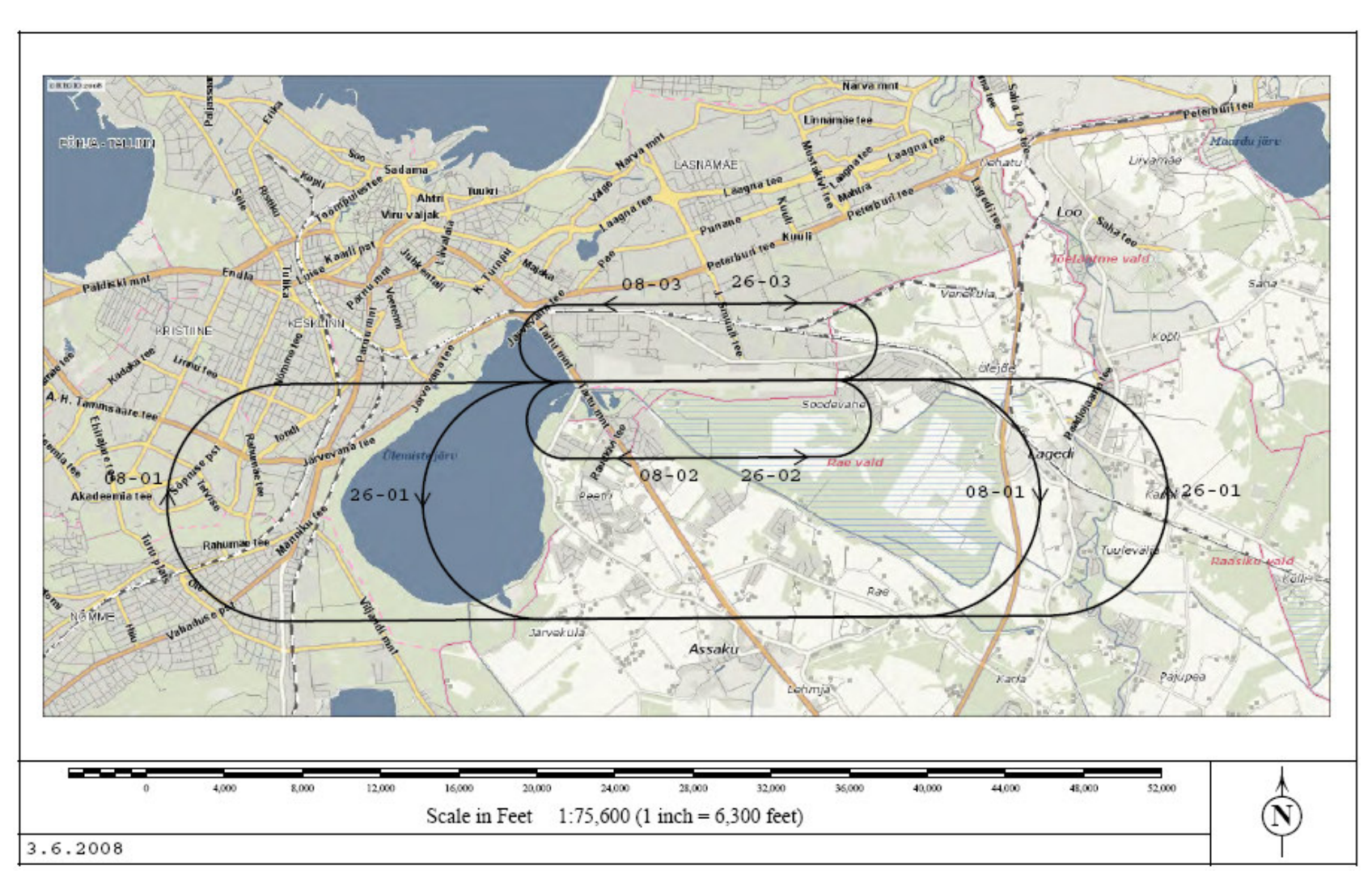

Fig 3. Tallinn Airport. Noise map according to Directive 2002/49/EC. Air corridors for training purposes

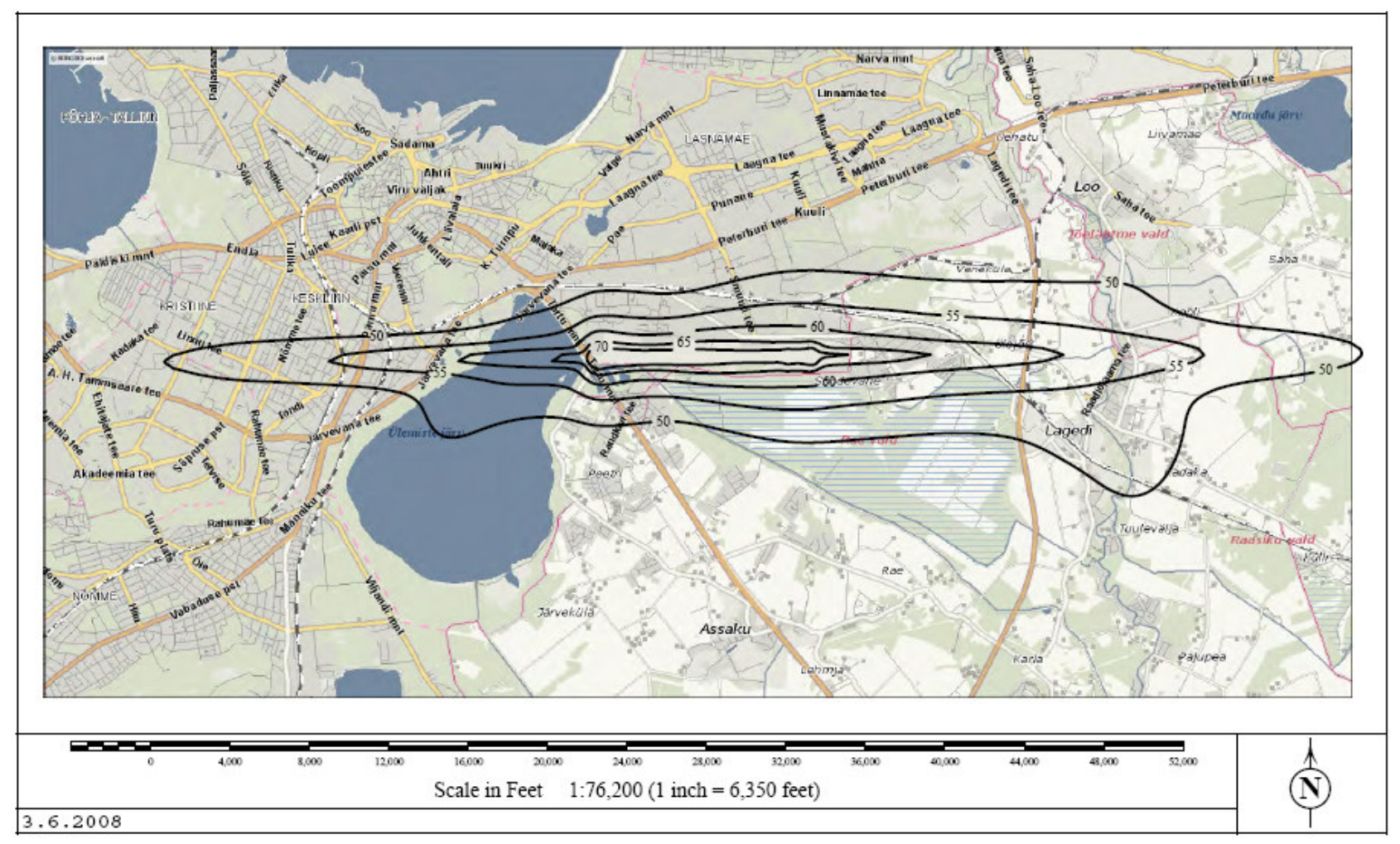

Fig 4. Tallinn Airport. Noise map according to Directive 2002/49/EC. Lden noise contours. 2006 average traffic 


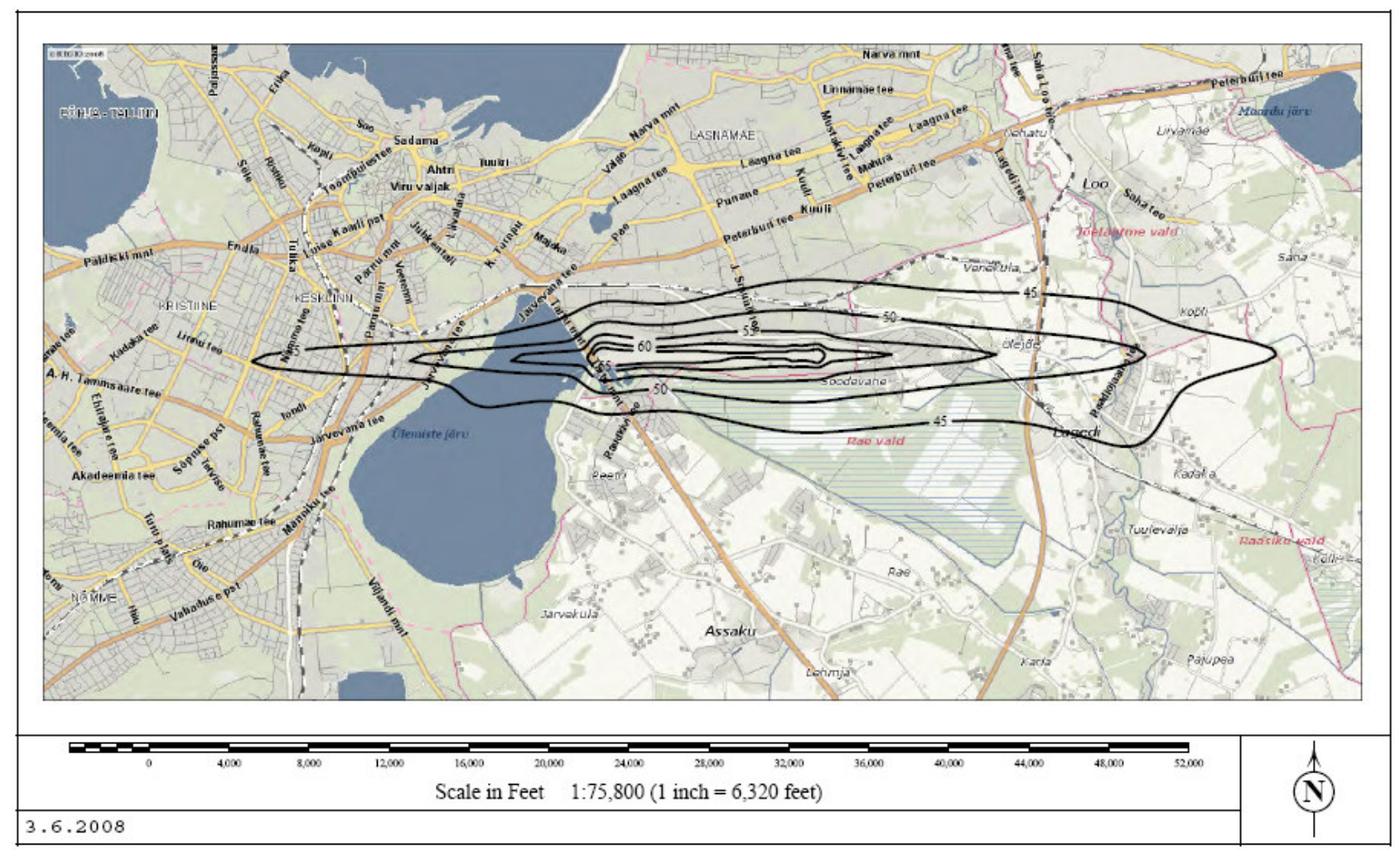

Fig 5. Tallinn Airport. Noise map according to Directive 2002/49/EC. Lnight (23-07) noise contours. 2006 average traffic

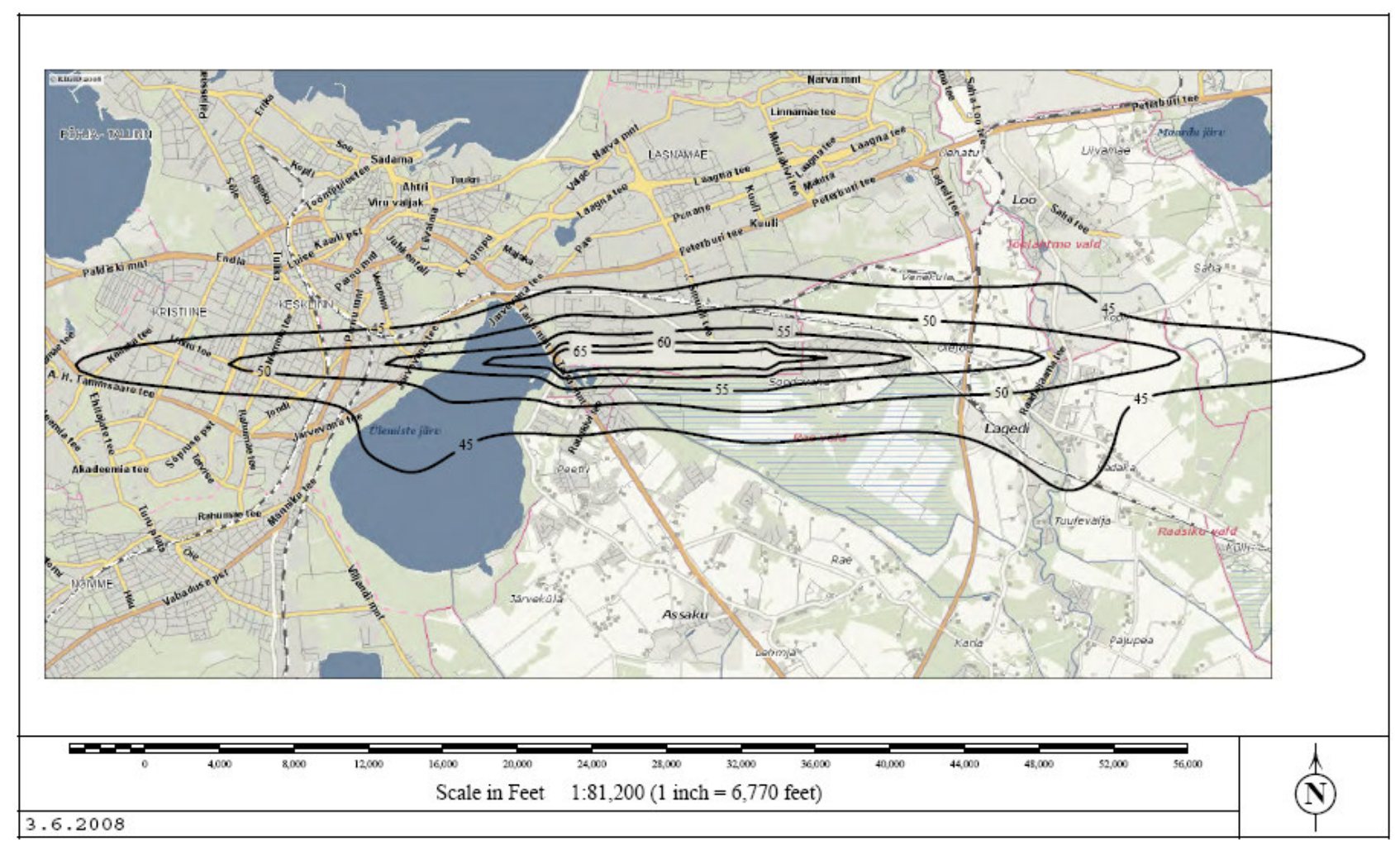

Fig 6. Tallinn Airport. Noise map according to Directive 2002/49/EC. Lday (7-23) noise contours. 2006 average traffic 


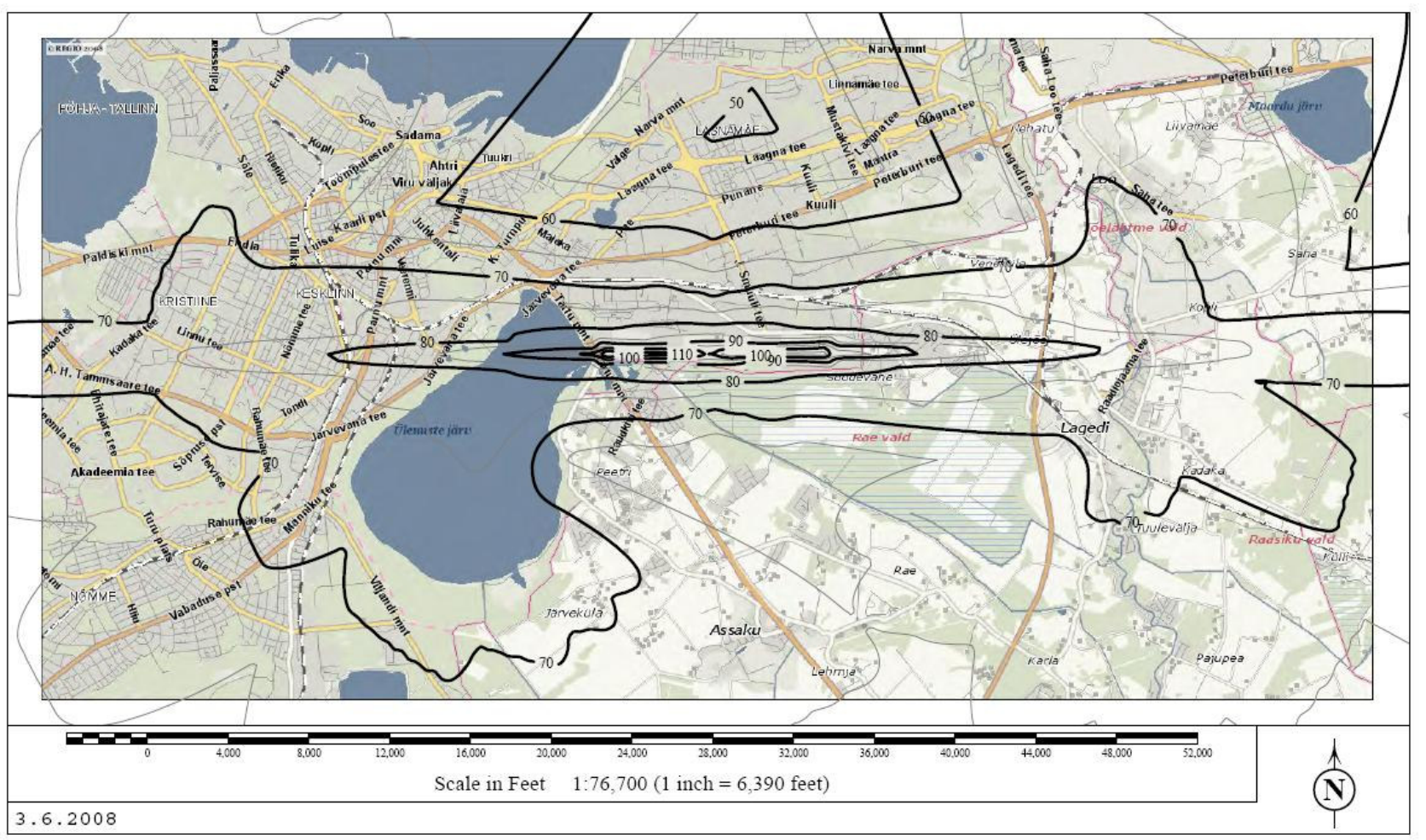

Fig 7. Tallinn Airport. Noise map according to Directive 2002/49/EC. LAmax (7-23) noise contours. 2006 average traffic

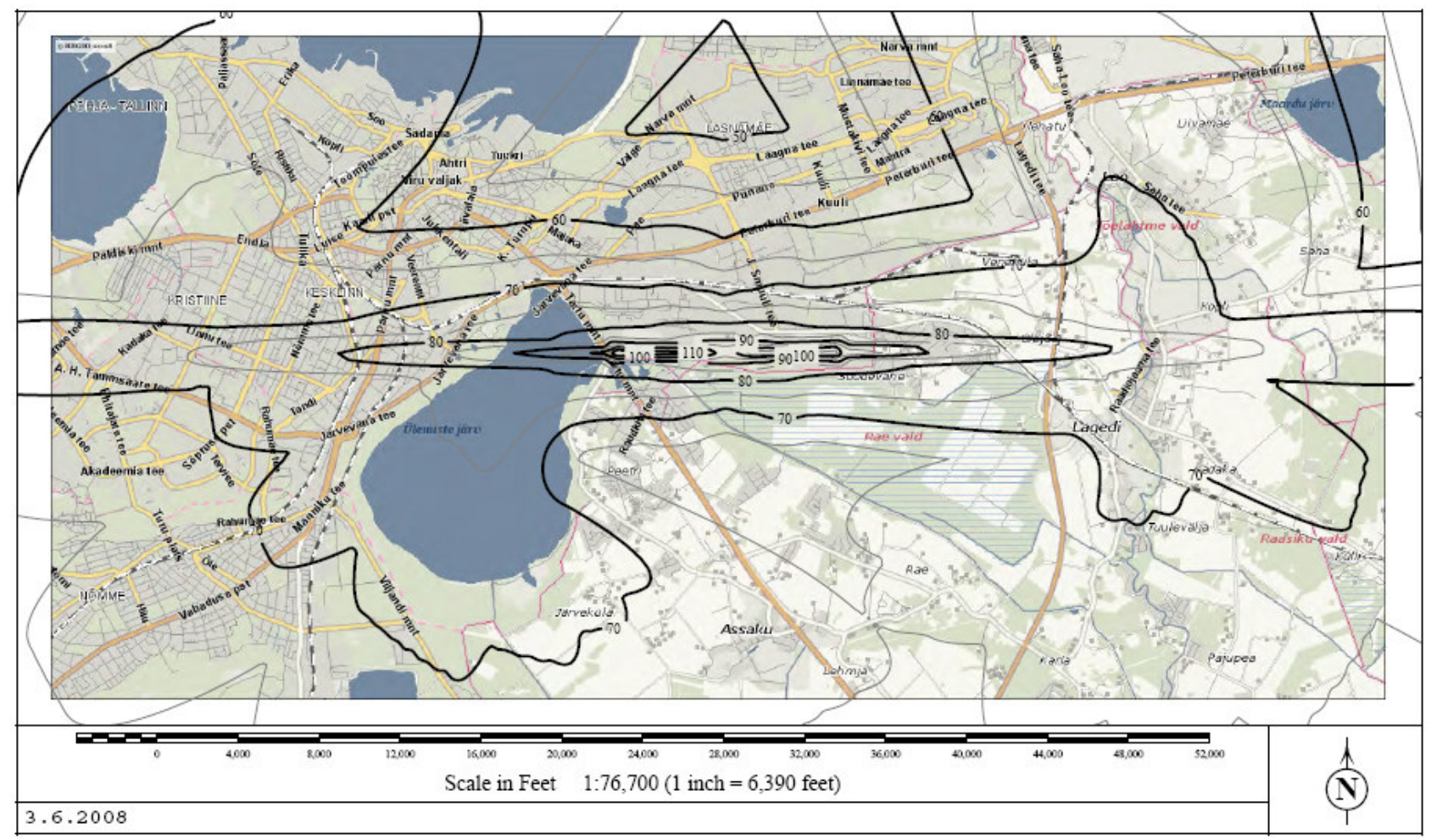

Fig 8. Tallinn Airport. Noise map according to Directive 2002/49/EC. LAmax (23-7) noise contours. 2006 average traffic 